\title{
Groundwater Arsenic Contamination in West Bengal: Current Scenario, Effects and Probable Ways of Mitigation
}

\author{
Tanmoy Kumar Dey ${ }^{1, \star}$, Priya Banerjee ${ }^{2}$, Madhurima Bakshi ${ }^{2}$, Abhirupa Kar ${ }^{2}$, \\ Somdeep Ghosh ${ }^{2}$ \\ ${ }^{1}$ Laboratory of Food Science and Technology, Food and Nutrition Division, University of Calcutta, \\ Kolkata, India \\ ${ }^{2}$ Department of Environmental Science, University of Calcutta, Kolkata, India \\ *E-mail address: tanmoydey7@gmail.com
}

\begin{abstract}
During the past two decades, Arsenic (As) contamination via groundwater has become a serious issue worldwide and is now a major concern in the Indo-Bangladesh Gangetic delta. Arsenic enters human body through contaminated groundwater consumed as drinking water. Food safety in this region is also facing severe consequences as bio-accumulation of Arsenic is occurring in food crops irrigated with As-contaminated water. Chronic exposure to Arsenic can cause not only cancerous and non-cancer health effects. Reports suggest that about $20 \%$ population in West Bengal is highly affected. Various techniques are being introduced to provide arsenic-free drinking water at an affordable cost. But a rigorous change in habit and mind set for procuring safe drinking water in those surviving in As-contaminated zones is the most essential step towards curbing the fatal consequences of As exposure. Harvesting rain water and utilization of proper purification techniques can be considered a possible alternative of safe drinking water.
\end{abstract}

Keywords: Arsenic; Gangetic delta; Groundwater; Health; Skin lesions

\section{INTRODUCTION}

Over the past two or three decades, occurrence of high concentrations of arsenic in drinking-water has been recognized as a major public-health concern in several parts of the world. It is now recognized that millions of people from India have been endangered by the prospect of consuming water contaminated with arsenic at levels greater than the guideline value of acceptable level set by the World Health Organization (Flanagan et al, 2012) (10 $\mu \mathrm{g} /$ liter); more than $95 \%$ of them live in West Bengal (SOES, 2010). Adverse health effects of arsenic depend strongly on the dose and duration of exposure. Chronic intake of drinking water with elevated arsenic concentrations can cause the development of arsenicosis, the collective term for diseases caused by chronic exposure to arsenic. It includes several kinds of skin lesions and cancers, like hyperpigmentation, keratosis, gangrene, cancer of different internal organs (Smith et al., 1992; NRC, 1999; NRC, 2001). 
Several studies have suggested a strong association between poor nutritional status with clinical manifestations of chronic arsenicosis, resulted less detoxification in the liver and impaired urinary elimination of arsenic (Rahman et al., 2001; Haque et al., 2003; Mitra et al., 2004).

There is no specific medical treatment for these arsenic-related diseases. Uses of chelating agents may reduce the body burden by enhancing the elimination of arsenic through urine and salicylic acid ointments to provide temporary relief from keratosis (Bhattacharya et al., 2002; Smedley and Kinniburgh, 2002; Mandal and Suzuki, 2002).

The West Bengal alluvial plain is composed of three interconnected aquifer systems: the shallowest aquifer (extending up to 12-15 meters below the surface), the intermediate aquifer (35-46 meters), and the lower aquifer (70-150 meters). All aquifers are reported to be enriched in arsenic-bound minerals in varied concentrations (Stüben et al., 2003). In the affected areas, the aquifer sediments are capped by a layer of clay or silt which has effectively restricted entry of arsenic into the surface water (Smedley and Kinniburgh, 2002). However, humans are facing higher As-exposure through the tapping of groundwater sources after the introduction of domestic hand pumps and irrigation wells (Nickson et al., 2000).

\section{CHEMISTRY OF ARSENIC}

Arsenic is a very redox-sensitive element and its mobility and speciation are highly controlled by $\mathrm{pH}$ and Eh (redox potential) of the groundwater. Arsenic is stable in four oxidation states $(+5,+3,0,-3)$ under the normal Eh conditions in aquatic systems, but the predominant forms are inorganic oxyanions of trivalent arsenite $\left(\mathrm{As}^{3+}\right)$ or pentavalent arsenate $\left(\mathrm{As}^{5+}\right)$ (Smedley and Kinniburgh, 2002). The toxicity of different arsenic species varies in the order arsenite $>$ arsenate $>$ monomethylarsonate $>$ dimethylarsinate.

Trivalent arsenic is about 60 times more toxic than arsenic in the pentavalent state, and inorganic arsenic compounds are about 100 times more toxic than organic arsenic compounds (Jain and Ali, 2000). According to Lombi et al., (2000) the coarse textured soils are likely to yield a higher fraction of readily mobile Arsenic.

Most of the groundwater samples from the nine most affected districts of West Bengal contain very high concentrations of arsenic, dissolved iron, ammonium, phosphate and very low concentrations of sulfate and nitrate reflecting the reducing condition of groundwater. Arsenic may derive from reductive dissolution of iron and manganese (oxy) hydroxide and microbial oxidation of organic matter (Nickson et al., 1998; Anawar et al., 2001; Anawar et al., 2001) (Scheme 1).

\section{SOURCE OF ARSENIC IN GROUNDWATER}

The source of arsenic is geogenic. Arsenic is present in alluvial sediment of the Delta. The mechanism and cause of arsenic leaching from source has not yet been established. Theories like: 


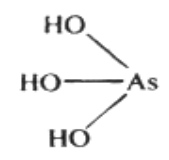

arsenous acid<smiles>C[As](=O)(O)O</smiles>

methylarsonic acid (MA)

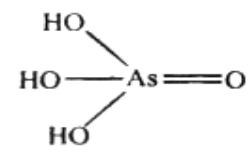

arsenic acid<smiles>C[As](C)(=O)O</smiles>

dimethylarsinic acid (DMA)

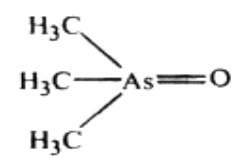

trimethylarsine oxide (TMAO)<smiles>CCC[N+](C)(C)C</smiles>

tetramethylarsonium cation (TETRA)<smiles>CCOC1O[C@H](C[As](C)(C)=O)[C@@H](O)[C@H]1O</smiles>

dimethylarsinoylribosides

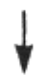

glycerol-ribose:<smiles>[R]#CCC(O)CO</smiles>

phosphate-ribose:<smiles></smiles><smiles>[R][S]=[R]</smiles>

sulfonate-ribose:<smiles>[R][Fe]CC(O)CS(=O)(=O)O</smiles>

sulfate-ribose:<smiles>[X]CCOCC[N+](C)(C)C</smiles>

arsenocholine (AC)<smiles>[R20]C1O[C@@H](C[N+](C)(C)C)[C@@H](O)[C@H]1O</smiles>

trimethylarsonioribosides<smiles>[R][CH]C[C@H](O)CO</smiles><smiles>[R][CH]CC(O)COS(=O)(=O)O</smiles>

Scheme 1. Arsenic compounds commonly detected in the environment (Abbreviations are in parenthesis) [Source: Goessler and Kuehnelt, 2002]. 
Oxidation of arsenopyrite, present in aquifer sediments, by atmospheric oxygen which enters the groundwater as the watertable get down because of excessive groundwater abstraction (Das et al.,1996; Chowdhury et al., 1999; Chakraborti et al., 2001).

Reductive dissolution of ferric-oxyhydroxide that contains sorbed arsenic (in Bengal and other alluvial aquifers) (Nickson et al., 1998; Nickson et al., 2000).

Carbon reduction (Ashraf et al., 2002)

Microbial reduction (Chatterjee et al., 2004; Yoshimura et al., 2004) is suggested by different authors.

According to Acharyya et al. (2000); Saha et al. (1997), the source of arsenic in grounwater of lower gangetic delta is considered to be the arsenic-rich sediments, transported from the Chotonagpur-Rajmahal highlands and deposited in sluggish streams under reducing conditions.

Continued extensive pumping triggered the reduction process by inducing movement of groundwater having highly reducing degraded organic products (Acharyya, 2006).

\section{STRETCH OF ARSENIC POLLUTION IN WEST BENGAL}

From the overall study on As in West Bengal and Bangladesh, it is revealed that the magnitude of the groundwater contamination is severe (Pearce, 1998; Smith et al., 2000). Groundwater arsenic contamination in the Lower Ganga basin of West Bengal, India, was first identified in July 1983 (Saha KC. Unpublished data).

Garai et al. (1984) reported 16 patients in three families from one village of 24 Parganas District. Saha (1984) further reported 127 patients with arsenical skin lesions.

In the combined areas of West Bengal and Bangladesh (Ganga-Padma-Bramhaputra delta), around 150 million people are at risk from arsenic-contaminated groundwater.

According to the reports of SOES, Jadavpur University, India, has identified tube wells with arsenic concentrations $\geq 50 \mu \mathrm{g} / \mathrm{L}$ in more than 3,000 villages. Based on Arsenic concentrations, West Bengal was classified into three zones: highly affected 9 districts (Malda, Murshidabad, Nadia, North-24-Parganas, South-24-Parganas, Bardhaman, Howrah, Hoogly and Kolkata, mainly in eastern side of Bhagirathi River) where average arsenic load is $>50 \mu \mathrm{g} / \mathrm{L}$ (upto $300 \mu \mathrm{g} / \mathrm{L}$ ) can be found in tube-wells; mildly affected 5 districts (in northern part) where average Arsenic load in tube-wells was below $50 \mu \mathrm{g} / \mathrm{L}$ (a few above $50 \mu \mathrm{g} / \mathrm{L}$ but all $<100 \mu \mathrm{g} / \mathrm{L}$ ) and Arsenic-safe 5 districts (mostly $<3 \mu \mathrm{g} / \mathrm{L}$ ) in western part.

The estimated population drinking Arsenic-contaminated water above 10 and $50 \mu \mathrm{g} / \mathrm{L}$ were $\sim 9.5$ and $\sim 4.6$ million respectively. In West Bengal alone, 26 million people are potentially at risk from drinking Arsenic-contaminated water above $10 \mu \mathrm{g} / \mathrm{L}$ (Chakraborti, 2003).

There is no generalized mitigation method applicable for all the affected regions due to (i) geographical and geomorphological variations, (ii) differing socio-economic and literacy conditions of people.

But whatever be the approach, for success at field level, awareness among the people and their wholehearted participation is need (Das et al., 2009). 


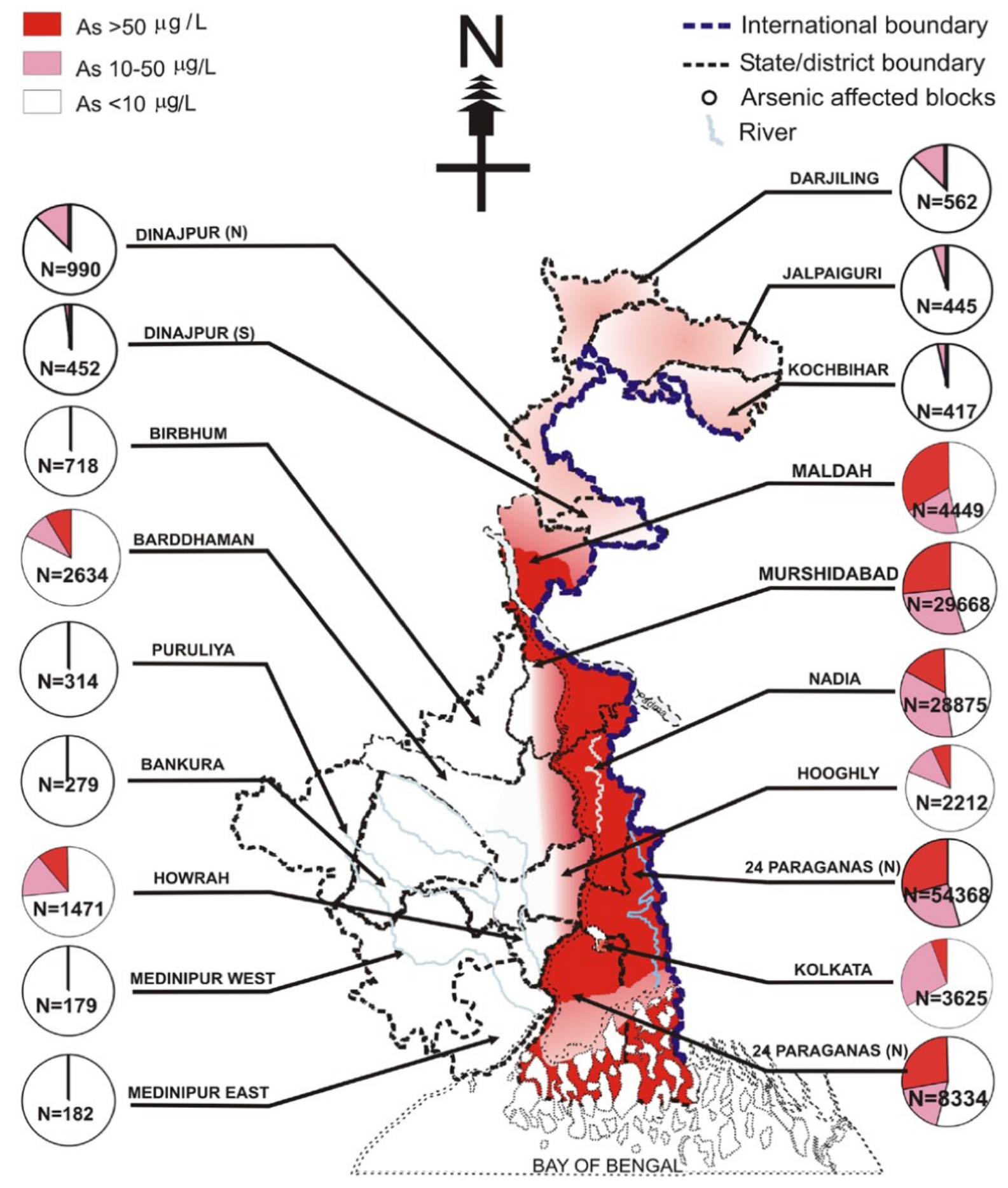

\section{ARSENIC POISONING}

\section{1. Bioaccumulation in plant}

In general plants takes up As(V) by phosphate transporter channels in plants grown on aerobic soils and metabolize it through phosphate transport channels (Tripathi et al., 2005). Because of their chemical similarity, arsenate competes with phosphates for root uptake and interferes with metabolic process like ATP phosphorylation and thereby exhibits its toxic 
effects. At higher concentrations, Arsenic has inhibiting effects towards plant metabolic processes growth (Marques and Anderson, 1986). At high concentrations, Arsenate in plants inhibits photosynthesis through interference of the pentose-phosphate pathway ( $\mathrm{Tu}$ and $\mathrm{Ma}$, 2002; Adriano, 2001). Arsenite[3+] penetrates the plant cuticle to a greater degree than Arsenate[5+] and generally results in the loss of turgor (USDHH, 2001).

The Chinese brake fern (Pteris vittata) was reported as the hyper accumulator of arsenic and thereby able to remove arsenic from soil. Some common plants of Bengal like Indian mustard (Brassica juncea), kachu sak (Colocasia antiquoram) and Kalmi sak (Ipomea reptans) have moderate arsenic accumulation capacity (Nickson et al., 1998). Food parts (e.g. potato skin, leafy vegetables, rice, wheat, cumin, turmeric powder and cereals) collected from the arsenic affected sites of the Murshidabad district of West Bengal, contained upto $373 \mu \mathrm{gKg}^{-1}$ (Goessler and Kuehnelt, 2002).

\section{2. Arsenic in human body}

Several studies in humans indicate that both Soluble Arsenic compounds [also the organoarsenicals] are well absorbed across the gastrointestinal tract (Hindmarsh and McCurdy, 1986; Bettley and O'Shea, 1975). Urinary excretion account for 55-80 \% of daily intakes of inorganic Arsenic in humans (Buchet et al., 1981; Crecelius, 1977; Mappes, 1977). The $\mathrm{As}^{3+}$ may undergo enzymatic methylation primarily in the liver to form MMA and DMA. Most Arsenic is excreted in the urine as a mixture of $\mathrm{As}^{3+}, \mathrm{As}^{5+}$, MMA, and DMA. Some Arsenic may remain bound to tissues, depending on the rate and extent of methylation. Monomethylarsonic acid may be methylated to DMA, but once methylated, neither MMA nor DMA is demethylated to yield $\mathrm{As}^{3+}$ or $\mathrm{As}^{5+}$. Arsenic accumulates in hair, nails, skin, bone, and muscle and its half-life in humans is between 2 and 40 days (Hindmarsh and McCurdy, 1986). Arsenic concentration in the hair, nail and urine is established as biomarkers for arsenic contamination (Chakraborti, 2003).

\section{3. Community health effects}

Drinking water and food is the most important source of Arsenic-contamination in humans (USDHH, 2001). The occurrence of inorganic Arsenic in drinking water has been identified as a risk-factor for human health even at relatively low concentrations. Hence, more stringent safer limits for Arsenic in drinking water have been proposed (USEPA, 1988). IARC (International Agency for Research on Cancer, 2004) has classified arsenic as a human carcinogenic substance, group 1. The toxicity of Arsenic in humans is a function of its rate of removal from the body.

Chronic exposure to elevated arsenic concentration in drinking water can cause the development of arsenicosis, the collective term for the diseases. It includes ailments like hyper-pigmentation, hyperkeratosis, gangrene, several kinds of cancers (Smith et al., 1992; NRC, 1999; NRC, 2001). Hyperpigmentation, an excess of skin pigmentation, is most often the first visible symptom.

Arsenic can induce oxidative damage to DNA, altered DNA methylation, altered gene expression, different types of chromosomal aberration, induction of protein-DNA cross links, apoptosis and altered regulation of DNA-repair genes, inhibition of thioredoxin reductase and inhibition of pyruvade dehydrogenase in vitro (NRC, 1999; Armstrong et al., 1984). The most characteristic effect of chronic exposure to Arsenic is hyperkeratosis (a darkening of the skin and appearance of small "warts" on the palms, soles, and torso, that's why it is known as Black foot disease (Chakraborti, 2003), which may ultimately develop into skin cancer 
(Hindmarsh and McCurdy, 1986). Early symptoms in humans include abdominal pain, vomiting, diarrhoea, muscular pain, and weakness, with flushing of the skin (Cullen et al., 1995; Moore et al., 1994; Fennell and Stacy, 1981). These symptoms are often followed by numbness of the extremities, muscular cramping. Further symptoms may show mottled skin and progressive deterioration in motor and sensory responses (Murphy et al., 1981; Civantos et al., 1995). Acute oral Arsenic poisoning at doses of $8 \mathrm{mg} \mathrm{As} \mathrm{kg}^{-1}$ and above have been reported to affect the respiratory system (Cullen et al., 1984). A number of studies in humans have shown that Arsenic ingestion may lead to serious effects on the cardiovascular system (Moore et al., 1994).

Studies have also revealed hepatic effects of Arsenic poisoning, indicated by swollen liver with elevated levels of hepatic enzymes in blood (Cullen et al., 1984). Recent studies have shown that GSH elevation is a natural reaction to arsenic attack which probably acts as a protective mechanism (McKinney, 1992; Mazumder et al., 1988). The situation becomes more critical when the availability of free thiol group is low (malnutrition/protein deficiency) and enhanced expression of toxicity can occur. This may be a possible explanation for wide spread clinical manifestation of arsenicosis among the rural, malnourished population in West Bengal. Arsenic induces haematological diseases like leucopaenia and thrombocytopaenia (Cullen et al., 1984; Saha, 2003; Guha Mazumder, 2008). No conclusive information on pregnancy outcome and infant mortality in relation to arsenic levels in drinking water is available in literature (Chakraborti et al., 2004).

\section{4. Mitigation Measures}

There is an acute scarcity of medicine to cure chronic Arsenic toxicity. Safe water, nutritious food and some physical exercise are only the proven measures to fight chronic Arsenic toxicity (Maeda, 1994). Proper watershed management and cost-effective utilization of available surface water along with the education of the villagers and their active participation appear to be the only solutions to resolving the present Arsenic crisis in the gangetic delta (Tripathi et al., 2005).

Inorganic Arsenic can undergo microbially mediated biochemical transformation, i.e., the hydroxyl group of arsenic acid is replaced by the $\mathrm{CH}_{3}$ group to form MMA, DMA, and TMA, thus get transferred into relatively non-toxic form (Frankenberger and Losi, 1995). The pathway of $\mathrm{As}^{5+}$ methylation initially involves the reduction of $\mathrm{As}^{5+}$ to $\mathrm{As}^{3+}$, with the subsequent methylation of $\mathrm{As}^{3+}$ to dimethylarsine by coenzyme S-adenosylmethionine (Pierce and Moore, 1982). Methylation is often enhanced by sulfate-reducing bacteria. Several fungal species also have shown ability to reduce Arsenic (USDHHS, 2000).

Some of the existing arsenic removal technologies can be reduced in scale and conveniently be applied at household and community levels for the removal of arsenic from contaminated water drawn by tube wells.

1. Oxidation: Arsenite can be oxidized by oxygen, ozone, free chlorine, permanganate, hydrogen peroxide etc. Atmospheric oxygen, hypochloride and permanganate are commonly used for oxidation in developing countries. Air-oxidation of arsenic is very slow but chemicals like chlorine and permanganate can rapidly oxidize arsenite to arsenate under wide range of conditions (Wegelin et al., 2000).

2. Solar Oxidation: It is a simple method of solar oxidation of arsenic in transparent bottles to reduce arsenic content of drinking water (Young, 1996). Ultraviolet radiation can catalyze the process of oxidation of arsenite in presence of other oxidants 
like oxygen (Ahmed et al., 2000). Experiments show that the process on average can reduce arsenic content of water to about one-third.

3. Co-precipitation and Adsorption processes: Water treatment with coagulants such as aluminium alum, activated alumina, ferric chloride and ferric sulfate are effective in removing arsenic from water. Ferric salts have been found to be more effective in removing arsenic than alum on a weight basis and effective over a wider range of $\mathrm{pH}$. In both cases pentavalent arsenic can be more effectively removed than trivalent arsenic (Pierce and Moore, 1982).

The Bucket Treatment Unit (BTU), designed for house-hold need, is based on the principles of coagulation, co-precipitation and adsorption processes. It consists of two buckets, each 20 liter capacity, placed one above the other. Chemicals are mixed manually with arsenic contaminated water in one of the bucket by vigorous stirring and then flocculated by gentle stirring. The mixed water is then allowed to settle for 1-2 hours. The water from the bucket is then allowed to flow into another bucket through a sand filter installed in the second bucket, very carefully avoiding the inflow of settled sludge in the first bucket. Now the second bucket practically contains treated water (Guha Mazumder, 2003).

There are a few promising treatment methods currently in use, including chelation therapy, that may reduce or at least arrest deterioration of chronic As-poisoned individuals. Two main treatments were dimercapto succinic acid (DMSA) and 2,3-dimercapapto-1propanesulfonate (DMPS). The study indicated that DMSA did not improve the skin lesions in chronic arsenicosis patients. In contrast, DMPS improved significantly chronic arsenicosis (Guha Mazumder et al., 2001). DMPS increased excretion of As in the urine several-fold (Simon et al., 2006). The increase in urinary Arsenic excretion during chelation therapy may be the key factor in DMPS therapy. Further research is needed to confirm the efficacy of this drug. Guha Mazumder, (2003) indicated that proteins in food may increase the elimination of inorganic Arsenic by increasing methylation. Hence, people exposed to Arsenic are advised to increase protein consumption from both animal and plant origins. In addition, retinoids and antioxidants have anti-keratinizing effects and may prevent cancer. Clinical ailments like chronic bronchitis, pulmonary disease, portal hypertension and peripheral neuropathy, must be treated regularly, so that the patient's health will not deteriorate. Early detection of cancers due to chronic arsenicosis, especially skin, urinary bladder and lung, can slow down the progress of disease (Khuda-Bukhsh et al., 2005). A potentized homeopathic remedy, Arsenicum album-30, has shown highly encouraging activities of various toxicity marker enzymes and compounds in the blood and suggest that the drug can alleviate As poisoning in humans (Chowdhury et al., 2001).

\section{DISCUSSION AND CONCLUSIONS}

Arsenic contamination has been spreading to newer areas and at the present situation, approximately 450 million people living in the Ganga-Meghna-Brahmaputra delta, is at risk (Maeda, 1994). It had been estimated that lifelong ingestion of arsenic $(1 \mu \mathrm{g} / \mathrm{kg}$ of body weight/day) is associated with an approximately $0.1 \%$ risk of skin cancer (Smith et al., 1992). This is very alarming as the level of arsenic contamination has been extremely high and its presence in multiple sources increases the exposure frequency. A water supply system requires high capital investment in installation and maintenance. A similar threat could be posed by piped water supply due to contamination through leakage in supply lines. Wide 
spread use of arsenic filters could cause further damage to the local ecosystem due to unplanned open disposal of the highly toxic sludge produced after their use. This might pollute soil and surface water, currently the only source of arsenic-free water.

Rainwater harvesting is a common technology used for collection and storage of rainwater. In many states of India mostly in the eastern parts, the average annual rainfall in eastern part of India is about 2,000 mm/year (Tripathi et al., 2005). So rain-water harvesting followed by proper purification can be used as a very cost-effective measure of getting Arsenic free drinking water.

Reports have shown the role of socioeconomic disparity in high occurrence of chronic arsenicosis and lack of participation in decision making. However, such an important social issue has not been addressed in policy and there is a need to ensure greater participation of marginalized and highly affected communities.

Socioeconomic study in arsenic-affected villages indicated that villagers were living in very poor conditions. Even now, many who are drinking arsenic-contaminated water are not even aware of this fact and its consequences (Das et al., 2009). Researchers at the School of Environmental Studies (SOES), Jadavpur University, India, have observed from their last 18 years' field experience in West Bengal, arsenic-affected people have also been facing serious social problems. Sometimes, the arsenic-affected patients are forced to maintain an isolated life (Dinesh et al., 2007).

Arsenic mitigation can be a double-edged problem. There are issues of devising scientifically sound, cost-effective, locally acceptable methods which should be sustainable through community involvement. For the mitigation program to be successful, it is essential to develop comprehensive management plans involving adequate medical, paramedic and infrastructural support within the umbrella of primary health care is needed. A change in water use behaviour and tapping of newer water resources is essential, in view of ever depleting ground water. The governmental agencies and NGOs need to reach out to the poor sufferers of this deadly disease. We live with the hope that someday every man on the earth will have access to arsenic free drinking water; someday the world will no longer bear the warts of arsenicosis.

\section{References}

[1] Ahmed. F., Jalil, M.A., Ali, M.A., Hossain, M.D. and Badruzzaman, A.B.M, 2000. An overview of arsenic removal technologies, In Bangladesh Environment, M.F.Ahmed (Ed.), Bangladesh Poribesh Andolon, Pp 177- 188.

[2] Chowdhury, U.K, Rahman, M.M., Mandal, B.K., Paul, K., Lodh, D., Biswas, B.K., 2001. Groundwater arsenic contamination and sufferings in West Bengal, India and Bangladesh. Environ. Sci. 8: 393-415.

[3] Armstrong, C.W., Stroube, R.B., Rubio, T., 1984. Outbreak of fatal arsenic poisoning caused by contaminated drinking water. Arch. Environ. Health 39: 276-279.

[4] Acharya, S.K., Lahiri, S., Raymahashay, B.C., Bhowmik, A., 2000. Arsenic toxicity of groundwater in parts of the Bengal basin in India and Bangladesh: the role of quarternary stratigraphy and holocene sea-level fluctuation. Environ. Geol. 39: 11271137. 
[5] Acharyya, S.K., 2006. Arsenic Contamination in Groundwater Affecting Major Parts of Southern West Bengal and Parts of Western Chattisgarh: Source and Mobilization Process. Curr. Sci. 82(6): 740-744.

[6] Adriano, D.C., 2001. Trace Elements in Terrestrial Environments: Biogeochemistry, Bioavailability and Risks of Metals, 2nd ed., Springer, New York.

[7] Anawar, H.M., Akai, J., Kamaki, K., Terao, H., Yoshioka, T., Ishizuka, T., Safiullah, S., Kato, K., 2001. Geochemical occurrence of arsenic in groundwater of Bangladesh: sources and mobilization processes. J Geochem Explor. 2(3): 109-131.

[8] Anawar, H.M., Akai, J., Ishizuka, T., Takahashi, T., Yoshioka, T., Kato, K., 2002. Diagenetic control on arsenic partitioning in sediments of the Meghna delta, Bangladesh. Environ. Geol. 41: 816-825.

[9] Ashraf, A.M.., Harvey, C.F., Swartz, C.H., Badruzzaman, A.B.M., Keon-Blute, N., Yu, W., 2002. Arsenic mobility and groundwater extraction in Bangladeshi aquifer. Science 298: 1602-6.

[10] Bhattacharya, P., Frisbie, S.H., Smith, E., Naidu, R., Jacks, G., Sarkar, B., 2002. Arsenic in the environment: a global perspective. In: Sarkar B, editor. Handbook of heavy metals in the environment. New York: Marcell Dekker, 147-215.

[11] Bettley, F.R., O'Shea, J.A., 1975. The absorption of arsenic and its relation to carcinoma. Br. J. Dermatol. 92: 563-568.

[12] Buchet, JP., Lauwerys, R., Roels, H., 1981. Comparison of the urinary excretion of arsenic metabolites after a single oral dose of sodium arsenite, monomethylarsonate or dimethylarsinate in man. Int. Arch. Occup. Environ. Health 48: 71-79.

[13] Chakraborti, D., Basu, G.K., Biswas, B.K., Chowdhury, U.K., Rahman, M.M., Paul, K., 2001. Characterization of arsenic bearing sediments in Gangetic Delta of West BengalIndia. In: Chappell WR, Abernathy CO, Calderon RL, editors. Arsenic exposure and health effects. New York: Elsevier Science, Pp 27-52.

[14] Chakraborti, D., Mukherjee, S.C., Pati, S., Sengupta, M.K., Rahman, M.M., Chowdhury, U.K., Lodh, D., Chanda, C.R., Chakraborti, A.K., Basu, G.K.., 2003. Arsenic Groundwater Contamination in Middle- Ganga Plain, Bihar, India: A Future Danger? Environ. Health Pers. 111(9): 1194-1201.

[15] Chatterjee, D., Islam, F.S., Gault, A.G., Boothman, C., Polya, D.A., Charnock, J.M., 2004. Role of metal-reducing bacteria in arsenic release from Bengal delta sediments. Nature 430: 68-71.

[16] Chakraborti, D., Sengupta, M.K., Rahman, M.M., 2004. Groundwater arsenic contamination and its health effects in the Ganga-Meghna Brahmaputra plain. $J$. Environ. Monitor 6: 74-83.

[17] Chowdhury, T.R., Basu, G.K., Mandal, B.K., Biswas, B.K., Samanta, G., Chowdhury, U.K., 1999. Arsenic poisoning in the Ganges Delta. Nature 401: 545-6.

[18] Civantos, D.P., Rodriguez, A.L., and Aguado-Borruey, J.M., 1995. Fuminant malignant arrythmia and multiorgan failure in acute arsenic poisoning. Chest 108: 1774-1775.

[19] Crecelius, E.A., 1977. Changes in the chemical speciation of arsenic following ingestion by man. Environ. Health Perspect. 19: 147-150. 
[20] Cullen, N.M., Wolf, L.R., Stclair, D., 1995. Pediatric arsenic ingestion. Am. J. Emer. Med. 13: 432-435.

[21] Cullen, W.R., McBride, B.C., Reglinski, J., 1984. The reaction of methyl arsenicals with thiols: Some biological implications. J Inorg Biochem. 21: 179-193,

[22] Das, B., Rahman, M.M., Nayak, B., Pal, A., Chowdhury, U.K., Mukherjee, S.C., Saha, K.C., Pati, S., Quamruzzaman, Q., Chakraborti, D., 2009. Groundwater Arsenic Contamination, Its Health Effects and Approach for Mitigation in West Bengal, India and Bangladesh; Water Qual. Expo. Health 1: 5-21.

[23] Das, D., Samanta, G., Mondal, B.K., Chanda, C.R., Chowdhury, P.P., 1996. Arsenic in groundwater in six districts of West Bengal, India. Environ. Geochem.. Health 18:5-15.

[24] Dermatas, D., Moon, D.H., Menounou, N., Meng, X., Hires, R., 2004. An evaluation of arsenic release from monolithic solids using a modified semi-dynamic leaching test. J.Haz.Mater.116: 25-38.

[25] Fennell, J. S. and Stacy, W. K., 1981. Electrocardiographic changes in acute arsenic poisoning. Irish J. Medical Sci. 150: 338-339.

[26] Flanagan, S.V., Johnston, R.B. and Zheng, Y., 2012. Arsenic in tube well water in Bangladesh: health and economic impacts and implications for arsenic mitigation. Bull. World Health Organ. 90: 839-846.

[27] Frankenberger, W.T. and Losi, M.E., 1995. Application of bioremediation in the clean up of heavy metals and metalloids. In "Bioremediation: Science and Applications" (H. D. Skipper and R. F. Turco, Eds.), pp. 173-210. SSSA Special Publication No 43. (1995) SSSA, ASA and CSSA, Madison, WI.

[28] Garai, R., Chakraborty, A.K., Dey, S.B., Saha, K.C., 1984. Chronic arsenic poisoning from tubewell water. J. Ind. Med. Assoc. 82: 34-35.

[29] Goessler W. and Kuehnelt D., 2002. Analytical methods for the determination of arsenic and arsenic compounds in the environment. In: Frankenberger, W.T. Jr. (Ed.). Environmental chemistry of Arsenic. Marcel Dekker, New York, USA. Pp 27-50.

[30] Guha Mazumder, D.N., De, B.K., Santra, A., Ghosh, N., Das, S., Lahiri, S., Das, T., 2001. Randomized placebo-controlled trial of 2,3-dimercapto-1-propanesulfonate (DMPS) in therapy of chronic arsenicosis due to drinking arsenic-contaminated water. J. Toxicol. Clin. Toxic. 39: 665-674.

[31] Guha Mazumder, D.N., 2003. Chronic arsenic toxicity: clinical features, epidemiology, and treatment: experience in West Bengal. J. Environ. Sci. Health A38: 141- 163

[32] Guha Mazumder, D.N., 2008. Chronic arsenic toxicity \& human health. Review Article, Indian J. Med. Res. 128, October 2008, pp. 436-447.

[33] Haque, R., Guha Mazumder, D.N., Samanta, G., Ghosh, S., Kalman, N., Smith D., 2003. Arsenic in drinking water and skin lesions: dose-response data from West Bengal, India. Epidemiol. 14: 174-182.

[34] Hindmarsh, J.T. and McCurdy, R.F., 1986. Clinical and environmental aspects of arsenic toxicity. CRC Crit. Rev. Clin. Lab. Sci. (1986) 23: 315-347.

[35] Jain, C.K. and Ali, I., 2000. Arsenic: occurrence, toxicity and speciation techniques. Water Res. 34(17): 4304-4312. 
[36] Kapaj, S., Peterson, H., Liber, K. and Bhattacharya, P., 2006. Human Health Effects From Chronic Arsenic Poisoning-A Review, J. Environ. Sci. Health A, 41: 2399-2428.

[37] Khuda-Bukhsh, A.R., Pathak, S., Guha, B., Karmakar, S.R., Das, J.K., Banerjee, P., Biswas, S.J., Mukherjee, P., Bhattacharjee, N., Choudhury, S.C., Banerjee, A., Bhadra, S., Mallick, P., Chakrabarti, J., and Mandal, B., 2005. Can Homeopathic Arsenic Remedy Combat Arsenic Poisoning in Humans Exposed to Groundwater Arsenic Contamination? A Preliminary Report on First Human Trial, Advance Access Publication 19 October 2005.

[38] Lombi, E.,Sletten, R.S. and Wenzel, W.W., 2000. Sequentially extracted arsenic from different size fractions of contaminated soils. Water Air Soil Poll. 124: 319-332.

[39] Maeda, S., 1994. Arsenic in the Environment, Part 1: Cycling and Characterization (J. O. Nriagu, Ed.). Wiley, New York.

[40] Mandal, B.K., Suzuki, K.T., 2002. Arsenic around the world: a review. Talanta 58: 20135.

[41] Mappes, R., 1977. Experiments on excretion of arsenic in urine. Int. Arch. Occup. Environ. Health 40: 267-272

[42] Marques, I.A., Anderson, L.E., 1986. Effects of arsenite, sulfite, and sulfate on photosynthetic carbon metabolism in isolated pea (Pisum sativum-L, Cv Little Marvel) chloroplasts. Plant Physiol. 82: 488-493.

[43] Mazumder, D. N. G., Chakraborty, A. K., Ghose, A., Gupta, J. D., Chakraborty, D. P., Dey, S. B., and Chattopadhyay, N., 1988. Chronic arsenic toxicity from drinking tubewell water in rural West Bengal. Bull. World Health Organ. 66: 499-506.

[44] McKinney, J.D., 1992. Metabolism and disposition of inorganic arsenic in laboratory animals and humans. Environ. Geochem. Health 14: 43-48.

[45] Mitra, S.R., Guha Mazumder, D.N., Basu, A., Block, G., Haque, R., Samanta, S., 2004. Nutritional factors and susceptibility to arsenic-caused skin lesions in West Bengal, India. Environ. Health Pers. 112: 1104-1109.

[46] Mohan, D., Charles, U. and Pittman, Jr., 2007. Arsenic removal from water/wastewater using adsorbents - A critical review; J. Hazard. Mater. 142: 1-53.

[47] Moore, J.N., O’Callaghan, C.A., Berylne, G., 1994. Acute arsenic poisoning: Absence of polyneuropathy after treatment with 2,3-dimercaptopropanesulphonate (DMPS). $J$. Neurol. Neurosurg. Psychiatry 57: 1133-1135.

[48] Murphy, M.J., Lyon, L.W., and Taylor, J.W., 1981. Subacute arsenic neuropathy: Clinical and electrophysiological observations. J. Neurol., Neurosurg. Psychiatry 44: 896-900.

[49] National Research Council, 1999. Arsenic in drinking water. Washington, DC: National Academy Press. pp. 330.

[50] National Research Council, 2001. Arsenic in drinking water: 2001 update. Washington, DC: National Academy Press. p. 244.

[51] Nickson, R.T., McArthur, J.M., Burgess, W.G., Ahmed, K.M., Ravenscroft, P., Rahman, M., 1998. Arsenic poisoning of Bangladesh groundwater. Nature, 395: 338. 
[52] Nickson, R.T., McArthur, J.M., Ravenscroft, P., Burgess, W.G., Ahmed, K.M., 2000. Mechanism of arsenic release to groundwater, Bangladesh and West Bengal. Appl. Geochem. 15: 403-413.

[53] Pearce, F., 1998. Arsenic in the water. The Guardian. London, February 19, pp. 1-3.

[54] Pierce, M.L. and Moore, C.B., 1982. Adsorption of Arsenite and Arsenate on amorphous iron hydroxide, Water Res. 16: 1247-1253.

[55] Rahman, M., Chowdhury, U.K., Mukherjee, S.C., Mondal, B.K., Paul, K., Lodh, D., 2001. Chronic arsenic toxicity in Bangladesh and West Bengal, India - A review and commentary. Clin. Toxicol. 39: 683-700.

[56] Saha, A.K., Chakraborti, C. and De, S., 1997. Studies of genesis of arsenic in groundwater in parts of West Bengal. Indian Soc Earth Sci. 24: 1-5.

[57] Saha, K.C., 1984. Melanokeratosis from arsenic contaminated tube well water. Indian J. Dermatol. 29: 37-46.

[58] Saha, K. C., 2003. Review of arsenicosis in West Bengal, India: A clinical perspective. Crit. Rev. Environ. Sci. Technol. 33: 127-163.

[59] Smedley, P.L. and Kinniburgh, D.G., 2002. A review of the source, behaviour and distribution of arsenic in natural waters. Appl. Geochem. 17: 517-68.

[60] Smith, A.H., Hopenhayn-Rich, C., Bates, M.N., Goeden, H.M., Hertz-Picciotto, I., Duggan, H.M., et al, 1992. Review of cancer risks from arsenic in drinking water. Environ. Health Pers. 97: 259-267.

[61] Smith, A.H., Lingas, E.O., Rahman, M., 2000. Contamination of drinking water of arsenic in Bangladesh. A public health emergency. Bull World Health Org. 78: 10931103.

[62] SOES, 2010. Groundwater Arsenic Contamination in Ganga-Meghna-Brahmaputra (GMB) Plain. School of Environmental Studies, Jadavpur University, Kolkata, India. Accessed 26 Oct 2010.

[63] Stüben, D., Berner, Z., Chandrasekharam, D. and Karmakar. J., 2003. Arsenic enrichment in groundwater of West Bengal, India: geochemical evidence for mobilization of as under reducing conditions. Appl. Geochem. 18: 1417-1434.

[64] Tripathi, R.D., Srivastava, S., Mishra, S., Singh, N., Tuli, R., Gupta, D.K., Maathuis, F.J.M., (2005) Arsenic hazards: Strategies for tolerance and remediation by plants. Trends in Biotechnol. 25: 158-165.

[65] Tu, C. and Ma, L.Q., 2002. Effects of arsenic concentrations and forms on arsenic uptake by the hyperaccumulator ladder brake. J. Environ. Qual. 31: 641-647.

[66] United States Department of Health and Human Services (2000).

[67] USEPA, 1988. United States Environmental Protection Agency.; Special Report on Ingested Inorganic Arsenic. Skin Cancer; Nutritional Essentiality. EPA /625 /3-87/013, Washington, DC.

[68] Wegelin, M., Gechter, D., Hug, S., Mahmud, A., Motaleb, A., 2000. SORAS-a simple arsenic removal process. Accessed from:

http://phys4.harvard.edu/ wilson/mitigation/SORAS_Paper.html. 
[69] Wenzel, W.W., Kirchbaumer, N., Prohaska, T., Stingeder, G., Lombi, E., and Adriano, D.C., 2001. Arsenic fractionation in soils using an improved sequential extraction procedure. Anal. Chim. Acta 436: 309-323.

[70] Yoshimura, T., Akai, J., Izumi, K., Fukuhara, H., Masuda, H., Nakano, S., 2004. Mineralogical and geomicrobiological investigations on ground water arsenic enrichment in Bangladesh. Appl Geochem. 19: 215-30.

[71] Young, E., 1996. Cleaning up arsenic and old waste, New Scientist, 14 December: 22. 